2 LINGUACULTURE 2, 2019

\title{
INTRODUCTION: THE LIFE OF C.S. LEWIS
}

\author{
Joel D. HECK \\ Concordia University Texas, Austin, Texas USA
}

Clive Staples Lewis (known to his friends as Jack, a name that will be used throughout this article) was born on November 29, 1898, in Belfast, Northern Ireland, the younger brother of Warren Hamilton Lewis. Their father, Albert Lewis, was a successful lawyer in Belfast. His wife, Flora Hamilton, whom he had married on August 29, 1894, was the daughter of the vicar of St. Mark's Church, Dundela, a church in Belfast, Northern Ireland. While starting from a humble beginning, Lewis became known as a writer, speaker, radio broadcaster, apologist, and educator, and his books have sold more than two hundred and fifty million copies to this day. This article will show how his early life and education prepared him to become one of the most effective writers of the twentieth century.

\section{The Early Years}

During his early years Jack loved reading the stories of talking animals by Beatrix Potter, especially her book Squirrel Nutkin. This story spoke to a young boy who was part of a family that always had animals. Both Jack and Warren acquired a lifelong love of animals and kept animals in their home for the rest of their lives.

As Albert Lewis's work prospered, the Lewis family moved to a new home, which Albert had had built for his family and which they called Little Lea, on April 21, 1905. Lewis called Little Lea almost a major character in his life because that was the place where Jack and Warren made up stories almost before they could write. Jack also read a great deal from an early age. He was well read by the age of eight, and one of his more remarkable achievements was to read John Milton's classic, Paradise Lost, at age nine. Jack read all kinds of books, both those appropriate for young children and those not appropriate for them, many of them books about animals. This helped to form some of his ideas 
of what children's stories should be like and enabled him to mature far more quickly than the typical child. By the age of ten writing had become a habit.

Then tragedy struck. When the two brothers were at a rather tender age, their mother, Flora, contracted cancer, went through surgery, and eventually died. She died on August 23, 1908, when Jack was only nine years old and Warren thirteen. That same year Jack was sent to Wynyard School, near London, where his brother Warren had already begun, putting both of them in one of the worst schools in the history of British education. Jack left Wynyard when it closed in July 1910, for lack of pupils, but at Wynyard Jack acquired a love of the science fiction novels of H.G. Wells and other space-travel books. That fall he attended Campbell College in Belfast, in January he started at Cherbourg House in Malvern, and a year later he enrolled at Malvern College.

After two years at Cherbourg House, Jack won a scholarship to Malvern College, based on an excellent English essay he had written. During these years at Cherbourg and Malvern College, he developed a love for the music of the German composer Richard Wagner, the poetry of W. B. Yeats, Norse mythology, and the Classics. At Cherbourg House, in 1912 or 1913, however, while just fourteen years of age he came to regard himself as an atheist.

\section{Private Tutoring}

Jack never did enjoy the private school system, and on September 9, 1914, he went to study with W. T. Kirkpatrick at Great Bookham in Surrey. He lived with Kirkpatrick and his wife for $2 \frac{1}{2}$ years, learning how to think, reading the Classics in the original languages, studying French, Italian, and German, and exploring much of English literature and many other subjects. His tutor William T. Kirkpatrick (1848-1921) was a rationalist, a logician, and an atheist, but young Lewis revered Kirkpatrick as the man who taught him how to think.

In 1914, Jack also met Arthur Greeves for the first time, and these two became lifelong friends. Arthur's interest in art provided some balance for Jack, who was adopting a very rationalistic attitude during this time. Jack would write nearly three hundred letters to Arthur over the next half-century, describing what he was reading and writing as well as sharing various kinds of intimate experiences.

George MacDonald (1824-1905) was the Scottish writer who most influenced Jack in his journey toward Christianity. In March 1916, Jack read MacDonald's Phantastes and called it "a great literary experience.” He wrote that this book baptized his imagination, beginning his journey on the road from atheism to Christianity. During these years, as is true of every period in his life, Jack was also reading much more, from Edmund Spenser's Faerie Queene to John Milton, from the poets Keats and Shelley to W. B. Yeats, from John Bunyan's The Pilgrim's Progress to Geoffrey Chaucer's Canterbury Tales. 
After sitting for scholarship exams in Oriel College, Oxford, in early December, Jack received a letter on December 13, 1916, which said that University College had awarded him the second of their three open scholarships for classics. He later took entrance exams to Oxford University in March, and because of his success he received a letter saying he could come up to Oxford for the start of the summer term.

\section{Oxford University}

Jack arrived at University College, Oxford, on April 26, 1917, to begin his studies. Soon thereafter, he signed up for the Officers' Training Corps to train for the war and met "Paddy" Moore (1898-1918), who, with his mother Janie Moore and sister Maureen, was to have a great influence on him. Paddy and Jack made an agreement that if one of them survived the war and the other did not, the survivor would care for the parent of the deceased person. Jack's father was a widower, and Paddy's mother was separated from her husband.

Jack was soon commissioned as a second lieutenant in the Third Battalion of the Somerset Light Infantry. He was sent to the front line trenches in France and celebrated his nineteenth birthday while fighting in the First World War. He was later injured by shrapnel, but recovered and was able to return to Oxford in January 1919 to resume his studies.

As a soldier who had served for more than six months, Jack was excused from his remaining entrance exams. He published his first book during his first year at Oxford, a series of poems entitled Spirits in Bondage. The book was reviewed highly, but it was not received well by the public, since the poems, though often powerful in their expression, were also pessimistic, cynical, and often obscure.

\section{Mrs. Moore and Oxford}

In keeping his promise to his friend Paddy, Jack began to look after Mrs. Janie Moore and her daughter Maureen. They lived for eleven years in rented houses in various parts of Oxford, until they bought the Kilns in 1930, while Jack completed his studies, applied for various teaching positions at the university, and was eventually hired.

Jack's feelings towards his father had not been good since the death of his mother. But Albert loved his son and consequently agreed to support Jack for three years beyond graduation, knowing that teaching would be the best option for Jack's life's work. This enabled Jack to apply for various fellowships and lecturing appointments. Jack took the exams known as Greats in June 1922, which successfully completed his first bachelor's degree. 
Failing in an attempt to get a university fellowship, Jack decided to take a second degree, this time in English Language and Literature, which he accomplished in one year. As a result of this last set of exams, he was awarded a first-class honors degree. He now had three first-class honors-in Honour Moderations (1920), Greats (1922), and English Language and Literature (1923) — and two degrees.

\section{Teaching Positions}

However, Jack was now in poverty, trying to support three people with the stipend his father sent for one person. In May 1924, he was offered a full-time job at Oxford for one year. The philosophy tutor at University College, E. F. Carritt, was to spend a year at the University of Michigan. Jack would replace him and earn $£ 200$ for the year. Jack accepted. In the meantime, Jack applied for all available fellowships in philosophy and English. The very last one, which earned him the position he desired, was to teach English at Magdalen College. And so he became an Oxford don. He sent a telegram to his father on May 20, 1925: "Elected fellow Magdalen. Jack.” He started at an annual salary of $£ 500$, which ended his poverty.

Jack began his tutorial and lecture work at Magdalen College in October 1925. In the early years he was an extremely busy Tutor.

During the term he spent one evening each reading Anglo-Saxon, another reading Elizabethan plays with undergraduates, on another he would join J.R.R. Tolkien and others in a meeting of the Coalbiters to read the Sagas and Eddas in Old Norse, and other biweekly meetings, including one with a philosophical society. During these early years, he prepared lectures, read for tutorials and for pleasure, and also wrote the draft of his first great academic work, The Allegory of Love, a study of medieval love poetry.

\section{Dymer}

In 1926 his long narrative poem Dymer, which he had been writing for several years, was published. Dymer was the story of a man who begat a monster, which later killed Dymer, its father, and became a god. Dymer rebeled against authoritarianism and killed a lecturer. Then he searched for a mysterious bride. Dymer learned that he must grow up, overcome his fault, and accept his destiny before he would be ready for this bride. In the end Dymer learned that he must face and fight the very monster he had begotton. He did so, and he was quickly killed, but his courage set off a process of cosmic rebirth-plants blossomed, and the country was clothed with flowers. The book was published under the pseudonym Clive Hamilton on Sept. 20, 1926. Dymer was reviewed well, but it 
failed to impress many readers or sell many copies. Its failure helps to explain why Lewis enjoyed success later in life as a writer of prose.

\section{The Pilgrim's Regress}

While Jack drew closer to Christianity over many years-from 1916 to 1931his conversion took place during a motorcycle ride in 1931. He once described his thinking as moving from Atheism to Realism to Idealism to Theism (1930) to Christianity (Sept. 28, 1931).

In 1926, T. D. Weldon, tutor and lecturer at Magdalen College, but also a cynic and atheist, remarked that there was surprisingly good evidence supporting the historicity of the Gospels and the dying and rising of Jesus Christ. The effect on Jack was shattering, and it led him to reread the Gospels. This helped him to reconsider the reliability of the New Testament Gospels, and as a result he moved closer to Theism and Christianity.

Things accelerated when his father Albert Lewis died of cancer on September 24, 1929. Jack became remorseful over the way he had treated his father and began to see evil within himself. Then, in the Trinity term of 1930, he wrote, "I gave in, and admitted that God was God, and knelt and prayed; perhaps, that night, the most dejected and reluctant convert in all England."

( Surprised by Joy, p. 228)

More than a year later Jack had a midnight conversation on Sept. 19, 1931 with J.R.R. Tolkien and Hugo Dyson. Tolkien said that myths originate in God and that they preserve something of God's truth, although often in distorted form. Jack came to see that the Gospel story was also a myth, but one that happened to be historically true. His friend Hugo Dyson stated that Christianity works for the believer, providing him with peace and freedom from personal sins, something that especially appealed to Lewis at a time when he still felt badly about how he had acted toward his father. Shortly thereafter, Jack wrote to Arthur Greeves, "I have just passed on from believing in God to definitely believing in Christ .... My long night talk with Dyson and Tolkien had a good deal to do with it." (Collected Letters, Vol. 1, p. 974) The conversion occurred on Sept. 28, 1931, while Jack was sitting in the sidecar of Warren's motorcycle en route to the Whipsnade Zoo.

In December he told the vicar of his parish church in Headington Quarry and Adam Fox, Magdalen's Dean of Divinity, that he wanted to become a practicing Christian. He received communion for the first time since boyhood on Christmas Day at the Anglican Church in Headington. Coincidentally, Warren, at the time serving in the military in Shanghai with the Royal Army Service Corps, received communion on that same Christmas Day in 1931.

His first book after his conversion was The Pilgrim's Regress. This witty allegory was based on the work of John Bunyan and told the story of Jack's 
conversion. Published in May 1933, the book sold poorly. However, it showed his ability to demolish opposing points of view, especially liberal theology.

"Almost from the year of his conversion," writes biographer George Sayer, "he wanted to become an evangelist for the Christian faith."(p. 231) He would have to learn to write simply, as a layman to laymen. But he did in fact learn, and the millions of copies of his works that have been sold are testimony to that fact.

\section{The Kilns}

When Warren Lewis returned to England in April 1930, he and Jack went through their father's belongings at Little Lea, retaining some, giving away others, and discarding the rest. They used the money from the sale of Little Lea, along with the help of Mrs. Moore, to buy a house. In July they purchased the Kilns in the Oxford suburb of Headington Quarry, three miles from the center of Oxford. The Lewis brothers lived there for the rest of their lives.

Jack's early research resulted in a series of lectures on medieval thought and the first of his two great works of literary history and criticism, The Allegory of Love. Published on May 21, 1936, the book dealt with the origins of courtly or romantic love, and it contained a summary of the attitudes of the church fathers on sex and passion. On Spenser, especially Spenser's Faerie Queene, Lewis wrote, "In the history of sentiment his is the greatest among the founders of that romantic conception of marriage which is the basis of all our love literature from Shakespeare to Meredith.” (p. 360) Almost all later writers on Spenser make use of The Allegory of Love. It remains the number one book on the subject. The Allegory of Love and English Literature in the Sixteenth Century show Jack's greatness as a literary historian. Thanks very largely to Lewis, Spenser is once again regarded as one of the greatest English poets, having become almost unknown before Jack wrote The Allegory of Love.

The next year Warren was back in Shanghai in command of the Royal Army Service Corps depot, the part of the military that deals with the housing and feeding of soldiers. After eighteen years of military service, he retired in 1932 and moved into the Kilns with his brother and Mrs. Moore.

\section{The Inklings}

During the 1930s through much of the 1950s, Jack delighted in Tuesday morning meetings at the Eagle \& Child pub and in Thursday evening meetings in his Magdalen College rooms with the group of friends known as the Inklings. These people, many of them Oxford professors, met in local pubs and in one another's rooms to read aloud the various works they were writing. The first member of the Inklings was J.R.R. Tolkien, Bosworth Professor of Anglo-Saxon 
at Oxford University. He met C.S. Lewis in 1926, and eventually others were invited to join them.

This was the beginning of one of the most important literary friendships of the twentieth century. The duo became a trio in 1933 when Warren, now in retirement, joined them. In 1934 Hugo Dyson and Dr. Robert E. Havard (the Lewis family physician) made it a group. Nevill Coghill and Charles Wrenn sometimes came to the group, as did Owen Barfield and other friends of Jack who happened to be in Oxford on Thursday evenings. Charles Williams joined when his employer, Oxford University Press, moved its London office to Oxford during the Second World War.

The Inklings heard Jack's first attempts at science fiction, beginning with his first space-travel novel in 1937, Out of the Silent Planet. Favorable reviews did not help Out of the Silent Planet until a few years later, when Jack became famous through The Screwtape Letters and his radio broadcast talks. The scientific hope of conquering death was a real rival to Christianity, so Out of the Silent Planet provided another perspective on science gone awry.

In late 1939, the Second World War broke out. Jack was then forty years old and had published seven books, of which only two were somewhat successful. Before the end of the war his name would become widely known throughout the United Kingdom.

\section{World War Two}

With the beginning of the war, Jack decided to join the Oxford City Home Guard Battalion. That meant that he would spend three hours every Saturday morning from 1:30 a.m. to 4:30 a.m. watching the skies around Oxford for Nazi war planes. At the same time, Jack and Mrs. Moore put their house at the disposal of children evacuated from London and other cities because of German bombing. This helped Jack learn about children and enjoy them, thus opening the way for the Chronicles of Narnia.

In an attempt to reconcile the idea of a good God with the problem of evil, he wrote The Problem of Pain during the first autumn and winter of the war. The book was published in October 1940 and became a best-seller from the start. To this day, it is one of his most popular books.

Shortly thereafter he wrote The Screwtape Letters, imaginary letters from a senior devil to a junior devil on the art of temptation. In February 1941, he sent the thirty-one letters to The Guardian, a Church of England weekly, which published them over the next weeks from May through November 1941. Because much of his earnings came from religious writings, he gave to charity most of the royalties he earned from his religious books. The letters were put together into one volume, and The Screwtape Letters came out in book form in February 1942. Letters of appreciation poured in. The first edition of 2,000 
copies sold out before publication, and the book has sold millions of copies worldwide since.

\section{Speaker and Broadcaster}

As the war progressed, Dr. James Welch, director of religious broadcasting for the BBC, asked Jack to help in the work of religious broadcasting in order to raise the morale of the British people. The invitation came because of the success of The Problem of Pain. Although Jack disliked the radio, he accepted the invitation because he would be able to reach people who would not likely read his books. Welch engaged Jack for four fifteen-minute talks every Wednesday during August 1941. The talks were entitled "Right and Wrong: A Clue to the Meaning of the Universe?” The talks were very well received, and Jack received many letters about the series. He was asked by the BBC to give another talk to answer some of his listeners' questions, but more letters than ever arrived. He continued to receive much correspondence for the rest of his life, eventually receiving, and answering, an estimated 30,000 letters during his lifetime.

Because of the popularity of his talks, the BBC asked Jack to do another series, which was entitled "What Christians Believe." The first two series were then published under the title Broadcast Talks. Then he was asked to do a third series, which was entitled "Christian Behaviour," giving much practical advice on the Christian life. His final series was broadcast in early 1944. This final series was published as Beyond Personality and dealt with the nature of God, and all the talks were later published together in the volume known today as Mere Christianity. The term "mere Christianity" came from the 17th-century Christian writer, Richard Baxter, and it refers to the basic beliefs of Christianity that all traditions and denominations accept.

Beginning in January 1942, his Monday evenings were devoted to meetings of the Oxford Socratic Club, of which he was president and for which he was responsible to the university for the next twelve years. The Socratic Club arose because of a student who complained that there was no one with whom to discuss the sort of doubts and difficulties agnostics raise about God. It became the second largest society of the university and attracted some of the best-known speakers in the country, including Charles Williams, C. E. M. Joad, Anthony Flew, and Dorothy Sayers.

At the Socratic Club, Jack often spoke against two erroneous views: (1) that there was no objective morality, and (2) that Christianity was fundamentally a moral or ethical system. He fought the latter by saying that Christian ethics were far from unusual and were common to most religions and civilized people. Jack's policy of counterattack used at the Socratic Club, in some of his writings, at meal times, and in the Senior Common Room afterward made him many 
enemies. In addition, many university professors felt that a man's belief was a private affair and should not be written about. This opposition was one of several reasons why Lewis was never elevated to the position of Fellow, the highest faculty rank, at Oxford University, and which in turn led to his election, in 1954, to a position at Cambridge University.

\section{Voluminous Writing}

Between 1942 and 1946 C.S. Lewis published A Preface to Paradise Lost, That Hideous Strength, Beyond Personality, The Abolition of Man, Perelandra, and The Great Divorce. He also wrote a draft of the book Miracles, contributed many articles to such publications as The Spectator, The Guardian, and Time and Tide, and wrote letters to the editors of Theology, The Times Literary Supplement, The Listener, other newspapers, and also to many individuals. This marks the early 1940s as the most productive literary period of Lewis's life.

The two living individuals who most influenced Lewis were J.R.R. Tolkien and Charles Williams. Since 1908, Charles Williams had worked at Oxford University Press, first years as a proofreader, and then as an editor. He was as fluent and industrious as Jack. He wrote poetry, plays, novels, biographies, and literary criticism, but only his novels achieved any measure of success. He became a member of the Inklings when his office was moved to Oxford during the war. When he died unexpectedly in May 1945 during minor surgery, this profoundly affected Lewis. Lewis dedicated A Preface to Paradise Lost to Williams, a book that eventually caused a revolution in the teaching and interpretation of Milton. Charles Williams influenced Jack most deeply in That Hideous Strength.

During the middle of the war, Jack wrote Perelandra, the second book in his space trilogy. The story shows similarities to both Genesis and Paradise Lost. The book describes an Edenic world and an unfallen woman who faces temptations subtler than those of the biblical Eve. The Abolition of Man, a 1943 publication, was his most important pamphlet, which many consider to be the best existing defense of objective values and the natural law in the English language. That Hideous Strength (1945) was the last of his space-travel novels. He wrote it because of the prospect of civilization dominated by scientists who were intent on conquering nature; this horrified him. While most critics disliked it, the public did not. Nevertheless That Hideous Strength has been the most popular of his four novels.

Also during the war Jack read to the Inklings The Great Divorce, a story of a dream vision of heaven in which the narrator meets several people who are on holiday from hell. In it, he writes, "There are only two kinds of people in the end: those who say to God, 'Thy will be done,' and those to whom God says, 
'thy will be done.'”(p. 72) The Great Divorce was Jack's tribute to George MacDonald.

The book Miracles was inspired by Dorothy L. Sayers and published in 1947. During a meeting of the Socratic Club, held on February 2, 1948, Elizabeth Anscombe read a criticism of Jack's argument in Miracles that naturalism is self-refuting. A debate followed, and Jack did not fare well in a philosophical argument against a professional philosopher. However, the main argument of Miracles has since been defended and upheld by professional philosophers.

With the end of the war the evacuated children had gone, leaving Mrs. Moore in poor health. She spent most of 1947 in her bedroom. There were two maids to care for the house, but they quarreled with each other and sometimes with Mrs. Moore. Jack tried to keep peace. Under these rather trying circumstances, he began to write the best-known and most widely loved of all his books, the Chronicles of Narnia.

\section{The Chronicles of Narnia}

The idea for Narnia had come to him in 1939, but he did not complete his first book, The Lion, the Witch, and the Wardrobe, until nearly a decade later. The evacuated children who lived at the Kilns during the war provided some of his inspiration. One of them had shown interest in an old wardrobe, asking if she could go inside and if there were anything behind it.

But there were more influences than evacuated children during the war. As a child, Jack had read The Aunt and Amabel, by Edith Nesbitt, in which a magic world was entered through a wardrobe in a spare room. A pupil and friend, Roger Lancelyn Green, had written the children's story The Wood That Time Forgot, from which Jack took elements. Since age sixteen, Jack had had a picture in his mind of a faun carrying parcels and an umbrella in a snowy forest. Finally he decided to make a story out of that picture. The book was largely finished by the end of Christmas vacation, 1948.

Most people who knew Jack were astonished that he had written a children's story. The publisher doubted that it would sell, fearing that it might damage his reputation and the sales of his other books. Soon thereafter, however, Jack began a second story, entitled Prince Caspian, which was finished by the end of 1949. The Lion, the Witch, and the Wardrobe was published in 1950 in time for the Christmas gift market. One Narnia book was published each year between 1950 and 1956. The Voyage of the Dawn Treader was written by the end of February 1950; The Horse and His Boy by the end of July; and The Silver Chair was finished by the beginning of March 1951; The Magician's Nephew and The Last Battle followed. Most reviews of the Chronicles of Narnia were cautious, occasionally hostile, but the children loved the stories. The 
interpenetration of the natural by the supernatural runs throughout the entire series.

The theological content of The Magician's Nephew is the story of creation, the temptation in Eden, and the fall. Other stories have spiritual growth, death, judgment, hell, and heaven. Lewis's idea was for his stories to make it easier for readers to accept the Christian faith when they met it later in life. He hoped that they would be vaguely reminded of the somewhat similar stories that they had read and enjoyed years before.

Adults usually prefer the last two, The Magician's Nephew and The Last Battle, the latter receiving the Carnegie Medal, an English award for the best children's book of 1956. Children usually like The Lion, the Witch and the Wardrobe. All of them are bestsellers, having collectively sold in excess of one hundred million copies.

\section{Workload and Health Problems}

Because of his heavy workload, both at the University and at his home, Jack's health declined and during summer of 1949 an ambulance took him to the Acland Nursing Home. He had a high temperature, delirium, headache, sore throat, and swollen glands.

In late April 1950, Mrs. Moore was taken by ambulance to Restholme, an Oxford rest and nursing home. Jack visited her almost every day. She died of influenza on January 12, 1951. After her death he began again to take regular walks and sometimes went swimming. His health improved immensely.

In 1935 Jack had been engaged to write English Literature in the Sixteenth Century, one volume of The Oxford History of English Literature series. Over the next two decades he did much reading in preparation for this book, not wanting to express an opinion over a book he had not read. Eventually this book became his second major work of literary criticism and the best-selling book in the series. In this nearly 700-page book he crusaded against the humanist. He wrote about the Puritans, John Calvin, Martin Luther, William Tyndale, Sir Thomas More, Richard Hooker, Gavin Douglas, William Dunbar, John Donne, Edmund Spenser, Sir Philip Sidney, and Shakespeare's poems. The book has wit and humor on every page. The Clarendon Press, part of Oxford University Press, published it in the autumn of 1954.

In 1955, Lewis's autobiography, Surprised by Joy: The Shape of My Early Life, was published, telling the story of his life until the time of his conversion to belief in God. Whereas years earlier The Pilgrim's Regress had told that story allegorically, this book told the story in a straightforward manner. Strangely, the account of his childhood misery at school takes up a third of the book. But for Lewis, writing was often therapeutic, and this book appears to have enabled him to move past his horrible memories of Wynyard School. 
At the same time, his workload at Oxford had become excessive. When a Merton professorship of modern English literature became available in 1947, Tolkien, who was a Merton Professor of English, supported Jack's candidacy, but it was impossible for Jack to be elected. He had too many enemies. His former tutor, F. P. Wilson, was eventually elected to the professorship. The election for the Goldsmiths' Professor of English Literature was made in 1948, and Lewis was bypassed once again, this position going to Lord David Cecil. Still later, in 1951, the professorship of poetry was to be filled. Jack was nominated, but Cecil Day Lewis was promoted.

\section{Joy Davidman}

The death of Mrs. Moore in 1951 had given Jack the freedom to do things he otherwise would not have been able to do. Not only could he go away for holidays, but he could now develop friendships with women, marry, or even accept a professorship in another university. The woman he eventually married was Joy Davidman, and the university at which he eventually taught was Cambridge University.

Born in New York City, Joy's parents were Jews from Eastern Europe who had lost their faith. Joy became an atheist at the age of eight as a result of reading H. G. Wells's Outline of History. She wrote poetry in her teens, winning awards for her poetry, and enjoyed stories of the supernatural. She earned a B.A. degree at Hunter College, New York, in 1934, and the M.A. in English literature at Columbia University at the age of 20 . She eventually joined the Communist Party, became an energetic party worker, and continued to write poetry.

In 1942 at a Communist Party meeting, she met William Gresham, whom she later married. They had two children, David, born in 1944, and Douglas, born in 1945. Joy and William eventually became disillusioned with communism, but William also became disillusioned with marriage and left her. Later, Joy Davidman became a Christian and began reading C.S. Lewis. An American friend by the name of Chad Walsh, who had published the first biography of Lewis, C.S. Lewis: Apostle of the Skeptics, suggested that Joy write to Lewis. Her first letter arrived at the Kilns in January 1950. She began to consider how she could visit Oxford without much expense and without making her desire to meet Lewis crudely obvious. She received an invitation to stay with a pen pal she had acquired, Phyllis Williams, who lived in London. Joy crossed the Atlantic in September 1952 in the hope of getting to know Jack.

Joy wanted advice from Jack about her marriage, which was then still intact, and she wanted to discuss with Jack the book she was writing on the Ten Commandments. He invited her and her pen pal to lunch in his Magdalen College rooms. From the moment they met, Joy's ability to make him laugh was 
one thing he enjoyed about her. Another strength was her constant flow of sharp, almost outrageous comments. They did not meet again until December 6, 1952.

At that meeting, he invited her to spend Christmas at the Kilns. At that time she read some of his unpublished work, and he read the draft of her book, Smoke on the Mountain, told her how to improve it, and wrote an introduction that helped to ensure its success. Just before she left, she received a letter from Bill, which suggested a divorce. By the end of February she had come to agree with Bill that they should be divorced and she should have custody of the boys. Her problem now became finances, so she returned to the U.S. to settle the arrangements.

In November 1953, however, she returned to London and secured lodging for herself and the boys and a place at Dane Court, a prep school in Surrey. Jack invited Joy and her sons to spend four days at the Kilns in the middle of December 1953. Before they left, Jack gave David and Douglas a typescript of his Narnian chronicle The Horse and His Boy and told them that he was going to dedicate the book to them.

\section{Cambridge University}

In 1954 Jack accepted a teaching position at Cambridge. He disliked the way in which the syllabus of the English School at Oxford seemed to be developing, and he had been turned down for various promotions in Oxford. Friends and admirers at Cambridge had learned of his dissatisfaction at Oxford, raised the matter at a meeting of the university English faculty, and created the professorship of medieval and Renaissance English just for him.

At first, he declined the position because he thought that it required him to move to Cambridge. However, Jack's friends at Cambridge suggested that he reside at Cambridge during weekdays and at Oxford during weekends and during vacation. Consequently he accepted the position and started lecturing at Cambridge in January 1955. He gave his inaugural lecture as professor on his fifty-sixth birthday, November 29, 1954. His impressive inaugural lecture was entitled "De Descriptione Temporum" (literally, “On Describing the Times"). In this lecture, he overstated the idea that little is left of an earlier age, partly because he enjoyed being part of an embattled minority, but he made a strong case for the value of medieval literature.

Jack was given rooms at Magdalene College, Cambridge, richly paneled but less spacious than his rooms at Magdalen College, Oxford. He liked the town of Cambridge, smaller, quieter, and less industrial than Oxford. The fellows of his new college were more friendly and courteous, the atmosphere more relaxed. For the first time in his life, he had no ideas for books, but Joy Davidman came to his assistance and helped him kick around a few ideas. 


\section{More Joy}

Joy and the boys had stayed at the Kilns in the summer and during the Christmas holidays of 1954. In 1955 Joy and her sons moved into a three-bedroom, semidetached house in Headington, not far from the Kilns. Jack and Joy were now meeting nearly every day that he was in Oxford. During his holiday in Ireland, September 1955, Jack was considering whether to marry her in a civil ceremony, just to allow Joy and her sons to stay permanently in England, since the British Immigration authority was threatening to deport her.

In April 1956, Jack told George Sayer that Joy's permit to live and work in England would not be renewed. The only way she could stay was for her to marry an Englishman. When Jack met Sayer over the summer holidays, he told Sayer that the marriage had taken place. At this point he was not in love with Joy although he very much enjoyed her company.

In June 1956, Joy began to suffer from severe pains. While going to answer the telephone, she fell in her house and was unable to get up. X-rays showed she had cancer of the left femur and a malignant tumor in her breast, right leg, and one shoulder. She underwent three operations. Her illness brought Jack to the awareness that he might lose her and that he now loved her. Jack wrote to Arthur Greeves, "... so she must come and live here ... our marriage must shortly be published.” (Collected Letters, Volume 3, p. 812) On Christmas Eve, 1956, The Times ran this notice:

A marriage has taken place between Professor C.S. Lewis of Magdalene College, Cambridge, and Mrs. Joy Gresham, now a patient in the Churchill Hospital, Oxford. It is requested that no letters be sent.

Jack now agreed that the civil marriage should be solemnized by an ecclesiastical ceremony. The Church of England would not allow marriage by a divorcee, so a former pupil of Jack, the Reverend Peter Bide agreed to do the wedding. Jack and Joy enjoyed three years and four months of married life together from the date of their ecclesiastical wedding, March 21, 1957. Throughout 1958 Joy was quite well. She also made improvements in the house, which was much in need of renovation. In July, they flew on Jack's first airplane flight to vacation in Ireland. A year later Joy returned to the hospital in November of 1959 for a routine checkup. The cancer had returned.

At the instigation of Roger Lancellyn Green and Green's wife June, Jack and Joy went with the Greens on an eleven-day holiday to Greece during the Easter vacation of 1960. Jack enjoyed seeing places about which he had been reading for fifty years. But Joy's health continued to decline. On June 20, she was taken to the Acland Nursing Home, the cancer now in her liver and gallbladder. She returned to the Kilns on June 27. The end came on July 13. She died peacefully at about 10:15 that evening. 
The books that Joy inspired were the novel Till We Have Faces (1956), The Four Loves, Reflections on the Psalms, and A Grief Observed. Till We Have Faces is based on the myth of Cupid and Psyche. Orual, queen of Glome, is ugly but passionate, unloved, longing to love and be loved. She is also jealous and possessive. The story is largely one of her redemption. Sometimes Jack thought it was his best novel, and sometimes he considered Perelandra his best. The Four Loves (1960) analyzes four words for love-Affection, Friendship, Eros, and Charity, while Till We Have Faces depicts the loves in action. Reflections on the Psalms (1958) is Lewis's only book written about some part of the Bible. A Grief Observed (1961) is the most personal, telling us most about his relationship with Joy, but especially his grief after losing her. The book was so personal and intimate that it had to be published under a different name, lest people know it came from Lewis. Few copies were sold until it was reissued under his own name in 1964 after his death.

\section{The Last Years}

In the months after Joy's death, Lewis wrote one of his best books on literary criticism, An Experiment in Criticism. The book was not well reviewed in 1961, the year it was published, but within five years it was referred to as "a now classic broadside.” This book is the most influential of Jack's critical books, and it is also the least combative.

Jack's health was slowly declining. In June 1961 he experienced slight discomfort due to a seriously enlarged prostate. Improvement in his condition came in January 1962 and seemed to continue until 1963. Jack seemed almost fully himself by the spring of 1963 . However, Jack had permanently damaged his kidneys two years before. On July 16 he had a heart attack and went into a coma. Anointed with oil by an Anglican curate, he immediately awoke from the coma and asked for tea. However, his health never fully recovered from this heart attack, he resigned his position as Professor of Medieval and Renaissance English and his fellowship at Magdalene College in August and spent his last days rereading some of his favorite books. C.S. Lewis died on Nov. 22, 1963, just one week shy of his sixty-fifth birthday, the same day that the American Phave a resident John F. Kennedy was assassinated in Dallas, Texas.

\section{Works Cited}

Lewis, Clive Staples. The Allegory of Love: A Study in Medieval Tradition. Oxford: Oxford University Press, 1936. Print.

---. The Great Divorce. New York: The Macmillan Company, 1946. Print.

---. Surprised by Joy: The Shape of My Early Life. San Diego: Harcourt Brace Jovanovich, 1955. Print. 
---. Collected Letters, Volume 1. 1905-1930, edited by Walter Hooper. London: HarperCollinsPublishers, 2000. Print.

---. Collected Letters, Volume 3. 1950-1963, edited by Walter Hooper. London:

HarperCollinsPublishers, 2006. Print.

Sayer, George. Jack: A Life of C.S. Lewis. Wheaton: Crossway Books, 1994. Print.

Joel D. Heck teaches theology at Concordia University Texas, which includes courses in Old and New Testament and the life and writings of C.S. Lewis. He holds the Doctor of Theology from Concordia Seminary, St. Louis. He is the author or editor of fourteen books, including two books on C.S. Lewis. In 2005, his book, Irrigating Deserts: C.S. Lewis on Education, was published by Concordia Publishing House. In 2008 The Personal Heresy, authored C.S. Lewis \& E. M. W. Tillyard, was edited and reprinted by Heck. Dr. Heck spent the fall of 2004 in Oxford, working with Walter Hooper on Vol. III of Lewis's Collected Letters and the fall of 2012 in Cambridge, doing additional research on Lewis. His most recent book, From Atheism to Christianity: The Story of C.S. Lewis, was released earlier in 2017, also by Concordia Publishing House.

Email: joelheck2@gmail.com 